\title{
Geography Lesson Development Based Ecoliteracy
}

\author{
Muh. Sholeh \\ Students S3 IPS Studies Program SPS Education University of Indonesia \\ Lecturer Department of Geography FIS Semarang State University \\ Corresponding email: muh.5eh@gmail.com
}

\begin{abstract}
Knowledge and awareness of the importance of protecting the environment is the responsibility of society. Knowledge of global warming in the form of causes, processes, and their impact on human survival is absolutely necessary so that people have the initiative power to face the phenomenon. The learning process in formal education is one effective way to educate people so that they have the knowledge, skills, and enough awareness so that they can participate to maintain environments. Ecoliteracy is knowledge and awareness which is owned by the public about the environment, and the various aspects that follow. Ecoliteracy can be developed in all subjects, particularly subjects geography. As a study of the similarities and differences in the phenomenon of the geosphere, academic geography has a direct responsibility to raise awareness of the importance of protecting the environment. The learning model to develop ecoliteracy a challenge for teachers for each material, classroom and school environment has characteristics which must be taken into consideration based learning development ecoliteracy.
\end{abstract}

\section{Keywords -Ecoliteracy, Geography}

\section{INTRODUCTION}

UN Resolution dated October 21, 2015 determines the Sustainable Development Goals (SDGs), which contains ,17 goals with 169 targets covering a broad range of sustainable development issues, Including ending poverty and hunger, improving health and education, making Cities more sustainable, combating climate change, and protecting oceans and forests (Press Release UN, 2015).

The main theme is sustainability of development to improve people's lives and protect the planet for future generations. Development is a process of improving the quality of life in accordance ideals of the nation. Improving quality of life include increased welfare, education, health, environment, safety, and other aspects of taking care of fairness, equity, and sustainability. Development is a process in which the relationship between human activities takes place with the surrounding environment. Utilization of natural resources into economic activity in the name of development, so that the process must be controlled to ensure development does not harm the environment and does not sacrifice the next generation.

In Indonesia, the construction should be carried out with due regard to the principles of justice and the preservation of the environment so that development truly in accordance with the development goals as defined in the preamble of the 1945 Constitution, which is to protect the entire Indonesian nation and the entire homeland of Indonesia and to promote the general welfare, educating the nation, and participate implementing world order based on freedom, lasting peace and social justice.

\section{METHOD}

This study used a qualitative approach with the method of literature, a critical assessment of the literature in the form of reference books, research reports, scientific and popular journals, notes, encyclopedias, and other relevant documents concerning ecoliteracy and geography. Based on these studies further analysis to describe the notion of the geography-based learning ecoliteracy which include: sustainable development goals and the global challenge, understanding ecoliteracy, and learning geography "based ecoliteracy".

\section{FINDINGS DISCUSSION}

\section{A. Sustainable Development Goals and the Global Challenge}

The United Nations through a resolution issued on October 21, 2015 has determined the Sustainable Development Goals (SDGs), which consists of 17 destinations with 169 measurable achievement and deadlines that have been determined by the United Nations as a world development agenda for the benefit of humans and the planet.

The goals SDGs are: a) end poverty in all its forms everywhere, b) end hunger, achieve food security and improved nutrition, and promote sustainable agriculture, c) ensure healthy lives and promote well-being for all at all ages, d) ensure inclusive and equitable quality education and promote life-long learning opportunities for all, e) achieve gender equality and empower all women and girls, f) ensure availability and sustainable management of water and sanitation for all, g) Ensure access to affordable , reliable, sustainable, and modern energy for all, h) promote sustained, inclusive and sustainable economic growth, full and productive employment and decent work for all, I) build resilient infrastructure, promote inclusive and sustainable industrialization and foster innovation, $\mathrm{j}$ ) reduce inequality within and among countries, k) make cities and human settlements inclusive, safe, resilient and sustainable, 1) ensure sustainable consumption and production patterns, m) take urgent action to combat climate change and its impacts, n) 
conserve and sustainably use the oceans, seas and marine resources for sustainable development, o) protect, restore and promote the sustainable use of terrestrial ecosystems, sustainably managed forests, combat desertification, and halt and reverse land degradation and halt biodiversity loss, p) promote peaceful and inclusive societies for sustainable development, provide access to justice for all and build effective, accountable and inclusive institutions at all levels, and q) strengthen the means of implementation and revitalize the global partnership for sustainable development.

On the other hand, the world faces the tensions generated by the technological, economic, and social changes as reported by UNESCO (2015). They included tensions between the global and the local; the universal and the particular; tradition and modernity; the spiritual and the material; long term and short term considerations; the need for competition and the ideal of equality of opportunity; and the expansion of knowledge and our capacity to assimilate it. The world faces global challenges in the form of a) ecological stress and unsustainable patterns of economic production and consumption, b) greater wealth but rising vulnerability and growing inequalities, c) growing interconnectedness, but rising intolerance and violence, and d) human rights: progress and challenges.

Development understood as economic growth which has a positive effect on increasing prosperity. Population growth encourages the use of water, food, and wood continues to increase. Consequently the practice of exploitation of natural resources can't be controlled that cause climate change, environmental degradation, natural disasters, and biodiversity loss. The risk is greater in poor countries (UN, 2013).

In some countries the poverty rate decreased as the positive impact of economic growth achieved, but in some countries people experience a threat because jobs are narrowing even though gross domestic product has increased (ILO, 2014). The population growth is not in line with the growth in employment that caused the unemployment rate continues to increase. It happened in the area of East Asia, South Asia, and Sub-Saharan Africa. Another fact, inequality of wealth, where the amount of wealth concentrated in fewer people to the detriment of social cohesion and social disruption.

The development of information and communication technologies allow people to interact without geographical restrictions. They can share their knowledge and expertise in the service of sustainable development and in the spirit of solidarity. However, the tech technology also has implications in the form of ideological and political mobilization to promote exclusive world view that erode the spirit of tolerance. The crime rate also increased. The situation puts children and women as the dominant party as a victim (UN Women, 2013).

In the field of Human Rights is still discrimination against certain groups of people. Human rights is a universal aspiration, in which human dignity is respected and treated equally before the law. But power in some areas has led to the law do not behave similarly to humans. Gender issues are still loud sounds, especially in the labor sector. Women's access to the public areas need to be improved although there have been improvements in gender equality in access to health, education, employment and participation of women in social and political life (UN, 2013).

The Indonesian archipelago and rich in natural resources are directly confronted with the phenomenon of climate change and global warming is causing natural disasters such as floods, landslides, and wildfires. All of these events occurred repeatedly showing the public ecological literacy is still low which affects the wrath of nature (Ibrahim, 2016). Of course we do not want such events recurring, it is necessary efforts to increase public awareness of sustainable development

\section{B. Understanding Ecoliteracy}

According to the Oxford English Dictionary, literacy is the ability to read and write, and the knowledge or skills in a particular field that is more extensive. Literacy is conceived as a tool for the construction of knowledge that includes the use of reasoning or solving to gain new knowledge. UNESCO defines literacy as involving a continuum of learning in enabling individuals to achieve their goals, to develop their knowledge and potential, and to participate fully in their communities and the wider society (McBride (2013).

The industrial revolution that occurred in the UK by the end of the 18th century was a period of rapid industrial growth through the introduction and advancement of the machine, with far-reaching consequences of social and economic. People are required to have the ability to read, write, and count in order to become a skilled workforce in accordance with the demands of industrialization. The absolute skills catered for industrial workers should be able to read the manual work involved in writing communications, and other office activities. The sequence of events that encourage the emergence of literacy.

Ecological terms proposed by Ernst Haeckel (1834 - 1914), which is the scientific study of the relationships between organisms and their environment. An overall total of knowledge that studies the relationship between organisms and their environment that is both organic and inorganic. Ecology is the study of how households earth work. Ecology studying how living things can defend life by organizing the relationships between living things and inanimate objects in his place or environment (Smith, 2012).

According to Wardana (1999) of an organism will depend heavily on the presence of other organisms and the various components of the environment in the surrounding areas in order to maintain its viability. The presence of other organisms and the various components of the environment is needed for the purposes of food, protection, growth, and development.

The relationship between living things and between living things with their environment form a unity called ecosystems. Ecosystem consists of several elements, such as abiotic and biotic elements. Abiotic elements, among others, temperature, water, humidity, light, and topography, while the biotic 
elements are living creatures which consists of humans, animals, plants, and microbes. Ecology is also closely linked to the levels of organization of living things, namely population, community and ecosystem interplay and is a system that shows unity.

Orr (1992) (in McBride, 2013) proposes that ecological literacy emphasis on creating sustainable human communities and called for a fundamental reconstruction of the education system as a whole. The idea was put forward after he did extensive research that shows the occurrence of pollution, desertification, and poverty. The report proposed the concept of sustainable development, defined as "... development that meets the needs of the present without compromising the ability of future generations to meet Reviews their own needs". The idea received widespread support in an effort to reduce the accelerated destruction of the environment and natural resources. Ecological literacy is a process of education for sustainable development. Ecological literacy is an understanding of the principles of ecosystem organization and application of these principles to create sustainable human communities and society.

Capra (1999) defines ecoliteracy as an understanding of the principles of ecosystem organization and application of these principles to create a human community and a sustainable society. Essential element in ecoliteracy is using resources to ensure its availability in the future. There is no ban on exploiting natural resources to meet their daily needs, but must still be controlled so as not to cause damage that threaten its availability in the future.

If there are elements that were damaged, it will have an impact on existing systems. The balance will be disturbed thus encouraging nature seek balance through their own way are not necessarily comfortable for human life. Floods, landslides, global warming is an example of balancing process conducted independently by nature because there is one element that is damaged, either by human activity or other factors.

Ecoliteracy is to understand the ecosystem based on knowledge that has been acquired, then by understanding the emerging awareness of the importance of maintaining the ecosystem, and eventually were able to take action in their daily lives according to their respective capabilities. If you do not have the skills to process waste, minimize the use of resources that generate waste, and other actions that show empathy towards the environment.

According to McBride (2013) components of literacy ecology consists of a) Affect, b) ecological knowledge, c) socio-political knowledge, d) knowledge of environmental issues, e) cognitive skills, f) environmentally responsible behaviors, and g) additional determinants of environmentally responsible behaviors. The component is the development of ecological component that emphasizes environmental sustainability, and the introduction of spiritual, holistic component, and respect for the earth.
Ecology study center is the "man and nature" as an ecosystem. The position of man in this case does not ignore the role of other living creatures, as other living creatures also have an important role, also did not see a human being outside the system, but it does mean that humans and their behavior is part of an ecosystem that will also be negatively impacted if there damage to one part of the system. To maintain the ecological system in order to achieve the balance of this relationship, it is absolutely necessary condition is the existence of the harmonious relationship between man and his environment. This is where the role of humans in order to sustain the functions of each subsystem through the action of environmental preservation based on the knowledge, understanding, awareness, and real action, namely ecoliteracy.

\section{Learning Geography "Based Ecoliteracy"}

To address the current environmental crisis required a different way of thinking, and the future sustainability of development in the hands of young people as agents of change. Environmental education is key to meeting the challenges of sustainability and a more equitable society. In particular, education should foster the development ecolitercy, or the capacity to understand the natural ecosystems that support life on earth, and the skills necessary to be a steward for the environment (Rigolon, 2012).

Ibrahim (2016) offers three dimensions important in encouraging literacy ecological, namely a) preparing stuffing learning in school and community activists literacy with finesse "literacy ecology across the curriculum", b) spreadintroduce good practices community of breeders of nature as a model, and c) build a new relationship with nature. The first bid of Ibrahim challenged school institutions to contribute to the efforts to save the environment so that there is certainty sustainable development. The idea was rational enough to be applied in the teaching of geography in schools because of geography to study the phenomenon of the earth with an environmental standpoint, regional, in the spatial context. In academic geography as a discipline demanded to be able to respond to various environmental problems, both locally and globally.

According Sutikno (2008), in response to environmental problems multidimensional scale and local to global, geography confronted with questions related to the discipline of geography itself, namely: geographic how is capable of providing a real contribution to policy making in solving environmental problems dimensionless local to global sustainable manner? Geography is capable of providing a real contribution to policy making in solving environmental problems local to the global dimension in a sustainable manner is consistent geography examines the phenomenon of the geosphere with an environmental standpoint, the regional spatial context. Geography developed with regard to the development of science and technology. Geography is open to accept the presence of other sciences and together solve environmental problems. 
Geography is the science to support their lifelong and life boost. The scope of its study allows humans to obtain answers to questions surrounding world that emphasizes the spatial aspect, and ecological of human existence. Field study of geography upon the earth, aspects and processes that shape, causal and spatial humans and the environment, and human interaction with the place. As an integrative discipline, geography combines physical dimension of the human dimension in the review of the existence and human life in space and the environment (Permendiknas RI No. 22 of 2006).

Subjects geography build and develop the students understanding of the variations and the spatial organization of people, places, and environments on earth. Learners are encouraged to understand the aspects and the physical processes that shape patterns of the earth, ecological characteristics, and spatial distribution on the surface of the earth. In addition the students are motivated to actively and creatively to examine that culture and experience influence the human perception of places and regions.

Knowledge, skills, and values obtained in the subjects of geography is expected to build the ability of learners to behave, act smart, wise, and responsible in dealing with problems of social, economic, and ecological.

The learning objectives are in line with efforts to encourage ecoliterasi among the younger generation so that they have the knowledge, understanding, attitudes, awareness, skills, and take action in ensuring the sustainability of development in everyday life. The real action in question are everyday actions that show a caring attitude, like taking out the trash in the space provided, getting used to carry water in a bottle, to plant and care for, and participate in environmental conservation activities.

Geography teacher challenged implementing learning geography "based ecoliteracy" which encourages students to take concrete steps to participate in saving the environment. There are four areas that could be developed, namely: empathy, knowledge, concern, and action. In areas of empathy, teachers can develop some aspects, namely: respecting and loving the environment, responsibility, focus on local phenomena and specificities, and dealing with the fear and danger at nature. As for the area of knowledge, teachers can develop material: conserving resources and energy, system thinking and connecting actions to consequences, nature is everywhere, even in the city, alimentary education and healthy living, density and green transportation, and sources of energy. As for the area of concern and action can be tailored to the situation.

Ways in which to develop learning geography "based ecoliteracy" among others, a) associate the subject matter of geography with the real conditions in everyday life, b) discuss the identification of natural disasters caused by human activity, c) Working Group to identify groups of people who live peace with nature, d) Discussion of the public contribution to preserve the environment, and e) individual creative ideas of sustainable environmental actions of love.

\section{Linking the subject matter of geography with the real conditions in everyday life.}

Is an attempt to reconcile a theoretical geography material with inherent in the real world of everyday life. If the air temperature during the day was hot, the teacher can explain why the air temperature was hot that day, and how it impacts on the lives globally. Teachers can also insert messages if the neighborhood that day were in different weather. The contextual learning will encourage students to have knowledge of and concern for the environment.

\section{E. Discussions identification of natural disasters caused by human actions.}

As an attempt to explore the knowledge of students based on information obtained from the print, electronic, and other media about the events of natural disasters. Of these events, students in groups to discuss a brief description of the incident, the cause of the disaster, and the loss of what is experienced by the community. Students can also be guided associate these events with global issues, prevention efforts possible to do, as well as the contribution of what could be done to address the event.

\section{F. Working groups to identify groups of people who live in peace with nature.}

An attempt by the students to find a group of people, both in Indonesia and other countries who live in harmony with nature. How hallmarks of these communities, the positive aspects of what can be obtained, and also discuss what if students live in a situation like that. Through which students will gain additional knowledge about the existence of groups of people who are still faithfully preserving the environment by applying the principles of love of the environment. Students can also develop empathy towards environmental sustainability in everyday life.

\section{G. Discussion of the public contribution to preserve the environment.}

An effort that can be made public both locally and globally to contribute to protecting the environment through concrete actions everyday. Through group discussion followed by plenary in the class, each group can convey the idea of environmental conservation community to do either individually or in groups. Environmental conservation measures may include preventive measures such as saving water and energy, preferring to bring water in refillable bottles instead of buying bottled water, cleaning the home environment, and other preventive measures. The response action is how people act quickly to save the environment or responding to natural disasters.

\section{H. Individual creative ideas of sustainable environmental actions of love.}

An action that can be offered by students both individually and collectively. Students can use the experience of other communities that are proven successful in managing the environment and their own original idea. The creative idea is 
the idea proposed as a solution to the problems faced by using knowledge and awareness and skills possessed information. Typically creative ideas will emerge after the students discuss, because the discussions is the entrance of fresh ideas that will be useful also managed correctly.

These ways can be done by teachers to encourage the emergence ecoliteracy among students. Of all the ways to offer, of course, teachers have their own way that has been adapted to the conditions of students and the school environment. However, of all the possible ways can be applied by teachers, the most important factor was the example or real examples that can be demonstrated by the teacher in daily life. Teachers can give an example of how a person has ecoliteracy attitude. The behavior exhibited these teachers will mean a strengthening of the emergence of nature gives ecoliteracy attitude in students, especially in the subject of geography.

\section{CONCLUSIONS AND SUGGESTIONS}

The world faces global challenges, one of which the environmental crisis that requires cooperation between countries. Through the UN resolution on Sustainable Development Goals (SDGs) world start real action to overcome the existing problems. Such efforts require public participation individually through knowledge, understanding, awareness, and real action of environmental preservation. One group of people can learn from other people treat nature in a peaceful and wise.

As part of the ecosystem, humans have an obligation to maintain a balance in order to function subsystem contained in it can keep running. That balance is important in order to maintain the sustainability of life can be assured. Utilize natural resources as needed is an effort to maintain a balance and it can only be done by people who care about the environment. Ecoliteracy people realize the responsibility of the educational institutions, one of them in the learning process in schools, especially on the subjects of geography. Education should produce a civilized society that cares for the environment to ensure sustainable development.

\section{REFERENCES}

[1] BB.McBride, C.A Brewer, etc. 2013, "Environmental literacy, ecological literacy, ecoliteracy: What do we mean and how did we get here?," Journal Ecosphere. Volume 4, Issue 5 May 2013. Pages 1-20.

[2] Fritjof Capra, 1999, "Ecoliteracy: The Challenge for Education in the Next Century," Berkeley California. Center for ecoliteracy.

[3] Gufran, A. Ibrahim 2016, "Banjir dan Literasi Ekologis". Artikel Kompas edisi 11 Juli 2016, di halaman 6.

[4] International Labour Office, 2014, "Global Employment Trends 2014," Geneva, International Labour Office.

[5] M. Thomas, Smith, 2012, "Elements of Ecology," Pearson

[6] Peraturan Menteri Pendidikan Nasional Republik Indonesia Nomor 22 tahun 2006 tentang standar isi untuk satuan pendidikan dasar dan menengah.

[7] Rigolon, Alessandro, 2012, "A Greener Future: The Active Role of Place in Enhancing Ecoliteracy in Children," Journal of Architectural and Planning Research, Vol. 29, No. 3 (Autumn, 2012), pp.181-203.

[8] Sutikno, 2008, "Geografi dan Kompetensinya dalam Kajian Geografi Fisik (Materi Sarasehan Keilmuan Geografi)," Yogyakarta.

[9] UN DESA, 2013, "World Population Prospects: The 2012 Revision," New York, United Nations.
[10] UN Women, 2013, “A Transformative Stand-alone Goal on Achieving Gender Equality, Women's Rights and Women's Empowerment,” New York, UN Women.

[11] UN, 2013, “A New Global Partnership: Eradicate poverty and transform economies through sustainable development," Report of the High-level Panel of eminent persons on the post-2015 development agenda. New York, United Nations

[12] UN, 2015, "Press Release UN General Assembly’s Open Working Group proposes sustainable development goals,"

[13] United Nations Educational, Scientific and Cultural Organization, 2015, "Rethinking Education Towards a global common good?,".

[14] Wardhana Wisnu, 1999, "Dasar-dasar Ekologi. Disampaikan pada Pelatihan Monitoring Biologi Bagi Pengelola Taman Nasional Gunung Halimun," Stasiun Penelitian Cikaniki TNGH, 5-10 April 1999.

[15] World Bank, 2011, "World Development Report 2011: Conflict, Security and Development," Washington, DC, The World Bank. 